\title{
HUBUNGAN ASUPAN ZAT GIZI DENGAN KOMPOSISI TUBUH REMAJA
}

\author{
Naintina Lisnawati ${ }^{*}$, Irwan Haryanto ${ }^{2}$ \\ ${ }^{1}$ Universitas Diponegoro \\ ${ }^{2}$ Sekolah Tinggi Ilmu Kesehatan Holistik \\ *Korespondensi: Jl. Prof. Soedarto, SH Tembalang, Semarang, Email: naintina.lisnawati@live.undip.ac.id
}

\begin{abstract}
ABSTRAK
Latar Belakang: Masa remaja ditandai dengan perubahan komposisi tubuh yang disebabkan oleh keadaan hormonal dan gaya hidup. Kondisi tersebut memberikan pengaruh terhadap pola asupan makanan yang dikonsumsi remaja.
\end{abstract}

Tujuan Penelitian: Mendeskripsikan dan menganalisis hubungan asupan zat gizi dengan komposisi tubuh remaja.

Metode: Desain penelitian ini adalah cross sectional. Subjek penelitian adalah remaja di Kabupaten Purwakarta yang dipilih secara acak dan berjumlah 44 orang. Data mengenai asupan zat gizi diperoleh menggunakan Formulir Food Recall 2x24 jam, dan komposisi tubuh menggunakan Bio Impedance Analysis (BIA). Analisis data menggunakan uji Rank Spearman Test.

Hasil: Rerata berat badan dan Lean Body Mass (LBM) subjek penelitian masing-masing adalah $43,7 \pm 8,6 \mathrm{~kg}$ dan $33,8 \pm 5,2 \mathrm{~kg}$, sedangkan median massa lemak adalah $8,2 \pm 4,6 \mathrm{~kg}$. Tingkat kecukupan energi subjek sebagian besar tergolong kurang $(59,1 \pm 37,8 \%)$, begitu pula dengan asupan kalsium $(159,4 \pm 502,9 \mathrm{mg})$. Asupan energi, karbohidrat, protein, dan lemak berhubungan dengan komposisi tubuh subjek $(\mathrm{p}<0,05)$, sedangkan asupan zat besi $(\mathrm{Fe})$, kalsium $(\mathrm{Ca})$, kalium $(\mathrm{K})$, natrium $(\mathrm{Na})$, magnesium $(\mathrm{Mg})$, dan seng $(\mathrm{Zn})$ tidak signifikan berhubungan dengan LBM dan berat badan subjek $(p>0,05)$. Zn merupakan satu-satunya zat gizi mikro yang mempunyai korelasi dengan massa lemak $(p=0,032)$.

Simpulan: Zat gizi makro mempunyai hubungan dengan komposisi tubuh remaja di Kabupaten Purwakarta.

Kata kunci: Asupan Zat Gizi, Komposisi Tubuh, Remaja

\begin{abstract}
Background: Adolescence is characterized by changes in body composition caused by hormonal conditions and lifestyle. These conditions have an influence on the pattern of food intake consumed by adolescents.
\end{abstract}

Objective: To describe and analyze the correlation of nutritional intake and body composition of adolescents.

Method: This study used cross sectional design. Subjects of the study were adolescents in Purwakarta Regency which selected randomly amounted to 44 people. Nutritional intake data used Food Recall Form 2x24 hours and body composition measurement used Bio Impedance Analysis (BIA). Data analysis used Rank Spearman Test.

Results: Mean of subjects's body weight and lean body mass (LBM) were $43.7 \pm 8.6 \mathrm{~kg}, 33.8 \pm 5.2 \mathrm{~kg}$, respectively. Most of level of energy intake of subjects were less (59.1 $\pm 37.8 \%)$, so did calcium $(159.4 \pm 502.9 \mathrm{mg})$. Intake of energy, carbohydrate, protein, and fat correlated with body composition of subjects ( $p<0.05)$, while intake of iron ( $\mathrm{Fe})$, calcium $(\mathrm{Ca})$, Potassium $(\mathrm{K})$, Sodium (Na), Magnesium (Mg), and Zinc ( $\mathrm{Zn}$ ) not sigificantly correlated with body composition of subjects ( $p>0.05)$. Zn was being the only micronutrient which correlated to fat mass ( $p=0.032)$.

Conclusion: Macronutrients have significantly correlated with body composition among adolescents in Purwakarta Regency.

Keywords: Nutritional Intake, Body Composition, Adolescent 


\section{PENDAHULUAN}

Remaja berasal dari kata latin adolensence yang berarti tumbuh atau tumbuh menjadi dewasa. Istilah adolensence mempunyai arti yang lebih luas lagi yang mencakup kematangan mental, emosional sosial dan fisik. ${ }^{1}$ Pada masa ini tidak termasuk golongan anak tetapi tidak juga golongan dewasa atau tua. Presentase asupan zat gizi remaja skala nasional berdasarkan hasil survei konsumsi makanan individu (SKMI) pada Studi diet Total tahun 2014, menunjukkan proporsi asupan energi $<70 \%$ AKE pada remaja usia 13-18 tahun sebesar 52,5\%, sedangkan presentase remaja usia 13 - 18 tahun denga asupan protein $<80 \%$ AKP sebesar $48,1 \%{ }^{2}$ Hasil diatas secara umum menggambarkan rendahnya presentase tingkat kecukupan energi dan protein pada remaja.

Data Riskesdas tahun 2013 menunjukkan bahwa secara nasional prevalensi pendek $(\mathrm{TB} / \mathrm{U})$ pada remaja usia 5-12 tahun adalah 30,7\% (12,3\% sangat pendek dan 18,4\% pendek). Prevalensi pendek pada remaja usia 13-15 tahun adalah $35,1 \%(13,8 \%$ sangat pendek dan 21,3\% pendek). Prevalensi kurus (IMT/U) pada anak usia 5-12 tahun adalah 11,2\%, terdiri dari 4,0\% sangat kurus dan 7,2\% kurus. Prevalensi kurus pada remaja usia 13-15 tahun adalah 11,1 persen terdiri dari $3,3 \%$ sangat kurus dan $7,8 \%$ kurus. Sedangkan masalah gemuk pada anak usia 5-12 tahun masih tinggi yaitu 18,8\%, terdiri dari gemuk 10,8\% dan sangat gemuk (obesitas) 8,8\%. Prevalensi gemuk pada remaja usia 13-15 tahun di Indonesia sebesar $10,8 \%$, terdiri dari $8,3 \%$ gemuk dan $2,5 \%$ sangat gemuk (obesitas). ${ }^{3}$

Komposisi tubuh merupakan implikasi asupan makanan yang dikonsumsi oleh seseorang. Salah satu penelitian di Kabupaten Banyumas menunjukkan bahwa asupan zat gizi makro berhubungan dengan lingkar lengan atas (LiLA) remaja putri di daerah pedesaan. ${ }^{4}$ Hasil penelitian tersebut menunjukkan bahwa asupan zat gizi berkorelasi positif terhadap indeks antropometri, akan tetapi belum menganalisis sejauh mana asupan berperan terhadap besaran komposisi tubuh. Berdasarkan kajian secara teoritis, komposisi tubuh terdiri dari massa lemak (fat mass) dan massa non lemak (fat free mass). Seperti diketahui bahwa penelitian sebelumnya hanya menganalisis terkait hubungan asupan dengan LiLA remaja, dan belum mengkaji lebih dalam mengenai komposisi tubuh. Oleh karena itu, peneliti tertarik untuk menganalisis hubungan asupan zat gizi dengan komposisi tubuh remaja.

\section{METODE PENELITIAN}

Penelitian ini merupakan jenis penelitian observasional dengan desain cross sectional. Subjek penelitian adalah remaja di Kabupaten Purwakarta yang berjumlah 44 orang. Pengambilan sampel dilakukan dengan teknik Random Sampling. Variabel terikat dalam penelitian ini adalah komposisi tubuh yang terdiri dari massa lemak, lean body mass (LBM), dan berat badan. Sedangkan variabel bebas adalah asupan zat gizi yang terdiri dari total energi, asupan karbohidrat, asupan protein, asupan lemak, asupan zat besi (Fe), asupan kalsium (Ca), asupan kalium (K), asupan natrium $(\mathrm{Na})$, asupan magnesium $(\mathrm{Mg})$, dan asupan seng (Zn). Berat badan diukur menggunkan digital body scale, sedangkan LBM dan massa lemak diukur menggunakan Bio Impedance Analysis (BIA). Asupan zat gizi diukur menggunakan Formulir Food Recall $2 \times 24$ jam dan dianalisis menggunakan perangkat software komputer. Untuk melihat korelasi antara asupan zat gizi dan komposisi tubuh dilakukan analisis statistik dengan uji Rank Spearman Test.

\section{HASIL PENELITIAN}

Subjek dalam penelitian ini termasuk dalam kategori remaja dengan rerata usia 12 tahun $(12,95 \pm 0,68$ tahun), lean body mass (LBM) sebesar 33,8 $\pm 5,16 \mathrm{Kg}$, berat badan sebesar $43,7 \pm 8,6 \mathrm{Kg}$, dan median massa lemak sebesar 8,2 $\pm 4,6 \mathrm{Kg}$. Tingkat kecukupan zat gizi makro maupun mikro subjek dalam penelitian ini sebagian besar berada pada kategori kurang jika dibandingkan dengan angka kecukupan gizi (AKG) bagi orang Indonesia. Perhitungan tingkat kecukupan gizi subjek didasarkan pada usia, jenis kelamin, dan berat badan observasional. ${ }^{5}$ 
Tabel 1. Hubungan Asupan Zat Gizi dengan Komposisi Tubuh Remaja

\begin{tabular}{|c|c|c|c|c|c|c|}
\hline \multirow[b]{2}{*}{ Variabel } & \multirow[b]{2}{*}{ Median \pm SD } & \multirow[b]{2}{*}{ Min. } & \multirow[b]{2}{*}{ Max. } & \multicolumn{3}{|c|}{$p^{\mathbf{a}}$} \\
\hline & & & & $\begin{array}{l}\text { Massa } \\
\text { Lemak }\end{array}$ & LBM & $\begin{array}{l}\text { Berat } \\
\text { Badan }\end{array}$ \\
\hline $\begin{array}{l}\text { Tingkat Kecukupan Energi } \\
(\%)\end{array}$ & $59,1 \pm 37,8$ & 24,1 & 170,1 & $0,001^{*}$ & $0,001^{*}$ & $0,001^{*}$ \\
\hline $\begin{array}{l}\text { Tingkat Kecukupan } \\
\text { Karbohidrat (\%) }\end{array}$ & $22,8 \pm 41,4$ & 22,8 & 192,8 & $0,001^{*}$ & $0,004^{*}$ & $0,001^{*}$ \\
\hline $\begin{array}{l}\text { Tingkat Kecukupan Protein } \\
(\%)\end{array}$ & $61,8 \pm 46,5$ & 19,7 & 248,8 & $0,001^{*}$ & $0,001^{*}$ & $0,001^{*}$ \\
\hline $\begin{array}{l}\text { Tingkat Kecukupan Lemak } \\
\text { (\%) }\end{array}$ & $64,4 \pm 45,5$ & 5,4 & 204,3 & $0,003^{*}$ & $0,001^{*}$ & $0,001^{*}$ \\
\hline $\mathrm{Fe}(\mathrm{mg})$ & $6,1 \pm 8,7$ & 1,9 & 50,8 & 0,249 & 0,118 & 0,177 \\
\hline $\mathrm{Ca}(\mathrm{mg})$ & $159,4 \pm 502,9$ & 62,2 & 2289,3 & 0,582 & 0,217 & 0,271 \\
\hline $\mathrm{K}$ (mg) & $774,3 \pm 837,4$ & 310,2 & 3438,3 & 0,145 & 0,133 & 0,128 \\
\hline $\mathrm{Na}(\mathrm{mg})$ & $359,4 \pm 638,8$ & 22,3 & 3143,6 & 0,380 & 0,775 & 0,432 \\
\hline $\mathrm{Mg}(\mathrm{mg})$ & $144,4 \pm 68,4$ & 71 & 411 & 0,099 & 0,193 & 0,157 \\
\hline Zn (mg) & $4,7 \pm 3,2$ & 2,2 & 15,5 & $0,032^{*}$ & 0,176 & 0,057 \\
\hline
\end{tabular}

Median tingkat kecukupan energi subjek adalah $59,1 \pm 37,8 \%$ dan termasuk dalam kategori kurang. Persentase tingkat kecukupan energi minimal subjek adalah $24,1 \%$ dan maksimal adalah 170,1\%. Meskipun nilai minimal terdapat dalam persentase yang rendah, akan tetapi terdapat juga subjek yang mempunyai tingkat kecukupan energi diatas 100\%. Berdasarkan hasil analisis, tingkat kecukupan energi subjek mempunyai korelasi dengan massa lemak $(\mathrm{p}=0,001$; $r=0,651)$, LBM $(p=0,001 ; r=0,592)$, dan berat badan $(p=0,001 ; r=0,693)$. Total energi merupakan akumulasi dari asupan yang dikonsumsi oleh subjek dan merupakan unsur pembentukan komposisi tubuh. Dilihat dari nilai koefisien korelasi (r), dimana nilai $r>0,50$ pada ketiga variabel juga mengindikasikan adanya korelasi yang cukup kuat antara tingkat kecukupan energi dan komposisi tubuh.

Hal ini serupa dengan tingkat kecukupan karbohidrat, protein, dan lemak. Hasil analisis statistik juga menunjukkan bahwa ketiga variabel tersebut signifikan berhubungan dengan komposisi tubuh $(\mathrm{p}<0,05)$. Akan tetapi, jika dilihat dari nilai koefisien korelasi, ketiga variabel tersebut mempunyai sebaran nilai koefisien korelasi yang beragam. Pada tingkat kecukupan karbohidrat, nilai koefisien korelasi lebih tinggi pada massa lemak ( $p=0,001 ; r=0,558)$ dibandingkan dengan LBM $(p=0,004$; $r=0,429$ ). Hal ini menunjukkan bahwa karbohidrat lebih banyak diperlukan untuk penyusun massa lemak dibandingkan LBM. Selain zat gizi makro, beberapa zat gizi mikro yang diteliti dalam penelitian ini antara lain $\mathrm{Fe}, \mathrm{Ca}, \mathrm{K}, \mathrm{Na}, \mathrm{Mg}$ dan $\mathrm{Zn}$. Akan tetapi, berdasarkan hasil uji statistik, diketahui bahwa hanya $\mathrm{Zn}$ yang mempunyai korelasi terhadap salah satu indikator komposisi tubuh, yaitu massa lemak. Median Zn subjek adalah 4,7 $\pm 3,2$ mg dengan asupan minimal subjek 2,2 mg dan maksimal 15,5 mg. Meskipun sebagian besar subjek mempuyai asupan $\mathrm{Zn}$ dibawah AKG, namun terdapat hubungan yang signifikan antara asupan $\mathrm{Zn}$ dan massa lemak $(p=0,032)$.

\section{PEMBAHASAN}

Remaja merupakan sebuah fase peralihan antara anak-anak menuju dewasa, sehingga perubahan fisik maupun biologis sangat erat dipengaruhi oleh peran hormonal dan gaya hidup. Selain itu, aktifitas fisik dan asupan zat gizi juga sangat berpengaruh terhadap perubahan fisik khususnya pada komposisi tubuh. Penelitian ini menghubungkan keterkaitan antara asupan zat gizi dengan massa lemak, LBM, dan berat badan. Hasil menunjukkan 
bahwa zat gizi makro (total energi, karbohidrat, protein, dan lemak) mempunyai korelasi dengan massa lemak, LBM, dan berat badan, akan tetapi karbohidrat mempunyai nilai koefisien korelasi yang lebih kuat terhadap penyusunan massa lemak dibandingkan dengan LBM. Sebuah penelitian menyebutkan bahwa diet karbohidrat dapat digunakan sebagai alternatif untuk menjaga berat badan ideal subjek apabila diimbangi dengan aktifitas fisik yang tinggi. Hasil penelitian tersebut menunjukkan bahwa konsumsi karbohidrat yang tidak diimbangi dengan aktifitas fisik dapat menyebabkan kenaikan massa lemak sehingga berakibat pada peningkatan berat badan. ${ }^{6}$ Sejalan dengan temuan tersebut, sebagian besar subjek (75\%) dalam penelitian ini mempunyai aktifitas fisik ringan, sehingga mempunyai korelasi yang kuat terhadap penyusunan massa lemak.

Berbeda dengan hasil penelitian ini, sebuah penelitian di Amerika pada 77 anak usia pra-sekolah menunjukkan bahwa tidak ada korelasi antara asupan zat gizi makro dengan persen lemak tubuh. Hal tersebut disebabkan karena pada usia pra-sekolah tingkat aktifitas fisik mempunyai pengaruh yang besar terhadap terbentuknya komposisi tubuh, selain itu asupan zat gizi yang dikonsumsi juga tidak langsung diubah menjadi massa lemak dengan waktu yang singkat. ${ }^{7}$ Sejalan dengan penelitian Atkin et al (2007), sebuah penelitian di Utah, Amerika juga menunjukkan bahwa remaja yang diberi intervensi berupa produk minuman dengan komposisi protein dan kalsium yang tinggi tidak mempunyai pengaruh yang signifikan terhadap kenaikan berat badan khususnya pada massa lemak. Penelitian tersebut juga menunjukkan bahwa pemberian minuman dengan komposisi protein dan kalsium yang tinggi berperan dalam memperbaiki komposisi mineral tulang sehingga dapat mencegah kejadian osteoporosis. ${ }^{8}$

Berdasarkan analisis asupan gizi mikro, diperoleh hanya asupan $\mathrm{Zn}$ yang berhubungan dengan komposisi tubuh. Hasil tersebut sejalan dengan sebuah penelitian di Michigan bahwa Zn memegang peranan penting dalam regulasi konsentrasi serum leptin di hipotalamus. Jika konsumsi Zn meningkat maka konsntrasi serum leptin akan meningkat, begitu pula sebaliknya. Seperti diketahui, leptin merupakan salah satu hormon yang berperan dalam peningkatan nafsu makan, sehingga apabila subjek mengonsumsi makana dengan kadar Zn tinggi maka nafsu makan meningkat dan berdampak pula pada peningkatan massa lemak. ${ }^{9}$ Asupan $\mathrm{Fe}$ dalam penelitian ini tidak signifikan berhubungan dengan komposisi tubuh. Hal ini berbeda dengan penelitian yang dilakukan di Yunani, bahwa asupan $\mathrm{Fe}$ mempunyai pengaruh terhadap komposisi tubuh remaja. Hasil menunjukkan bahwa remaja gemuk mempunyai kecenderungan asupan Fe yang lebih rendah dibandingkan remaja yag tidak gemuk. ${ }^{10} \mathrm{Fe}$ berperan dalam metabolisme energi, jika seseorang mengalami defisiensi $\mathrm{Fe}$, maka pembentukan energi akan terganggu, sehingga asupan makanan yang dikonsumsi tidak dapat dipecah dan mengendap didalam tubuh.

\section{SIMPULAN}

Komposisi tubuh merupakan hasil dari gambaran asupan makanan yang dikonsumsi oleh seseorang, sehingga asupan makanan mempunyai peranan penting dalam penyusunan massa lemak maupun non lemak. Zat gizi yang signifikan berhubungan dengan komposisi tubuh Remaja di Kabupaten Purwakarta antara lain total energi, karbohidrat, protein, lemak, dan Zn. Penelitian selanjutnya diharapkan dapat mengobservasi lebih dalam mengenai pengaruh asupan zat gizi kaitannya dengan parameter biokimia, seperti konsentrasi serum leptin, interleukin, TNF- $\alpha$, maupun parameterparameter lain yang berkaitan dengan komposisi tubuh.

\section{DAFTAR PUSTAKA}

1. Hurlock, Elizabeth B. Psikologi Perkembangan : Suatu Pendekatan Sepanjang Rentang Kehidupan (edisi 5). Jakarta : Erlangga; 1991.

2. Badan Litbangkes Kemenkes RI. Studi Diet Total. Jakarta : 2014.

3. Badan Litbangkes Kemenkes RI. Riset Kesehatan Dasar. Jakarta : 2018. 
4. Zaki I, Sari HP, Farida. Asupan Zat Gizi Makro Dan Lingkar Lengan Atas Pada Remaja Putri Di Kawasan Perdesaan Kabupaten Banyumas. Prosiding Seminar Nasional. 2017: 435-41.

5. Gibson RS. Principles of nutritional assessment. 2nd ed. New York: Oxford University Press; 2005.

6. Nicholas et al. Effects of an Ad Libitum Low-Fat, High-Carbohydrate Diet on Body Weight, Body Composition, and Fat Distribution in Older Man and Woman. Arch Intern Med. 2004; 164: 210-7.

7. Atkin LM et al. Diet composition and body composition in preschool children. Am J Clin Nutr. 2000; 72: 1521.

8. Chan GM et al. Effects of dairy products on bone and body composition in pubertal girls. J Pediatr. 1995; 126 : 551-6.

9. Mantzoros et al. Zinc May Regulate Serum Leptin Concentrations in Humans. Journal of the American College of Nutrition. 1998; 17(3): 2705.

10. Hassapidou M et al. Energy Intake, Diet Composition, Energy Expenditure, and Body Fatness of Adolescents in Northern Greece. Obesity. 2006; 14(5): 855-62. 